\title{
FACTORS AFFECTING BIOCHEMICAL COMPOSITION OF SESTON IN AN EUTROPHIC RESERVOIR (PAMPULHA RESERVOIR, BELO HORIZONTE, MG)
}

\author{
BOËCHAT, I. G. ${ }^{1}$ and GIANI, A. ${ }^{2}$ \\ 'Departamento de Biologia Geral, Setor Ecologia, Programa de Pós-graduação em Ecologia, Conservação e \\ Manejo de Vida Silvestre, Instituto de Ciências Biológicas, UFMG, Avenida Presidente Antônio Carlos, \\ C.P. 486, CEP 31270-110, Belo Horizonte, MG, Brazil \\ ${ }^{2}$ Departamento de Botânica, Instituto de Ciências Biológicas, UFMG, Avenida Presidente Antônio Carlos, \\ C.P. 486, CEP 31270-110, Belo Horizonte, MG, Brazil \\ Correspondence to: Iola Gonçalves Boëchat, Rua Adelina Sales Pereira, 677, Bairro Planalto, \\ CEP 31720-440, Belo Horizonte, MG, Brazil, e-mail: iola@mono.icb.ufmg.br \\ Received February 1, 1999 - Accepted Juny 15, 1999 - Distributed February 28, 2000
}

(With 8 figures)

\begin{abstract}
Sestonic biochemical composition (lipids, proteins and carbohydrates) may change with varying environmental fluctuations. These changes and the effects in the nutritional status of algae consists of an actual increasing source of interest. The aims of this work were to establish the relationship between biochemical composition of seston and 1) a range of physical, chemical and climatological factors, and 2) the natural fluctuation in the species composition in phytoplankton assemblages of the Pampulha Reservoir, an urban eutrophic lake located in Belo Horizonte, MG. Seasonal changes in the biochemical composition were observed in this study. None of the considered abiotic factors alone seem to affect the biochemical composition. So the effects could only be understood by interactions among different environmental factors. On the other hand, the dominant algal groups probably have some influence in the observed changes in biochemical composition of seston.
\end{abstract}

Key words: biochemical composition, seston, seasonality.

\section{RESUMO}

Fatores que afetam a composição bioquímica do seston em um reservatório eutrofizado Reservatório da Pampulha, Belo Horizonte, MG

A composição bioquímica do seston (lípides, proteínas e carboidratos) pode variar com flutuações nas condições ambientais. Tais alterações e seus eventuais efeitos sobre o status nutricional das algas representa uma crescente fonte de interesse atualmente. Os objetivos deste trabalho são os de estabelecer a relação entre a composição bioquímica do seston e: 1) um conjunto de fatores físicos, químicos e climatológicos e 2) as flutuações naturais na composição em espécies do fitoplâncton do Reservatório da Pampulha, um lago urbano eutrófico localizado na cidade de Belo Horizonte, MG. Mudanças sazonais na composição bioquímica puderam ser observadas neste estudo. Nenhum dos fatores abióticos considerados parece afetar isoladamente a composição bioquímica do seston, de forma que sua influência só pode ser compreendida por meio das interações entre os diversos fatores ambientais. Por outro lado, os grupos algais dominantes provavelmente exercem alguma influência nas mudanças observadas na composição bioquímica do seston.

Palavras-chave: composição bioquímica, seston, sazonalidade. 


\section{INTRODUCTION}

The biochemical composition of algae is one of the most important studies of planktonic communities as nutritional status of primary producers could be an usefull prediction to account for the energetic disponibility in the trophic foodweb. Most of the recent interests in the biochemical composition are suggested by studies in applied phycology in areas such as aquaculture, the nutrional quality of foods fed to cultured animals, and alternative energy sources (Sicko-Goad \& Andersen, 1991).

Lipids, proteins and carbohydrates are the most important biochemical components in algal biomass. Lipids are rich in $-\mathrm{C}=\mathrm{O}$ - bounds, providing much more energy in oxidation processes than other biological compounds. Mainly owing to their high reduction levels, they constitute a convenient storage material for living organisms. In algae they are widely distributed, specially in several resistence stages (Miller, 1962).

Proteins have crucial functions in all the biological processes. Their activities can be described by enzimatic catalysis, transport and storage, mechanical sustentation, growth and cellular diferentiation control (Stryer, 1988). Protein, as well as lipid contents in phytoplankton, can have an important effect to the energetic disponibility in the trophic foodwebs. Some carbohydrates serve as food sources and storages, while other ones are cell wall constituents (structural polyssacarides), just as a lot of them have still uncertain functions (Percival, 1979).

The biochemical composition in algae can change with altering environmental conditions (Fábregas et al., 1995; Fernandéz-Reiriz et al., 1989). In nature, changes in phytoplankton community can modify the food quality and quantity (Butler, 1994). The effect of these variations for a set of algae species has been well exposed by understanding algal physiology and to answer more specific questions (Lourenço et al., 1997).

Some studies demonstrated that certain algae species are considered "good food supplements" while other ones are considered "bad food supplements" (Ahlgren et al., 1990). However, the real reasons why some species can stimulate a better growth and reproduction than others are still not understood (Ahlgren et al., 1990). There are many aspects that should be considered to describe the nutritional status of algae, and its quality for zooplankton, like the size range, cell wall digestibility, toxicity and the chemical composition as well. Much attemption has been directed to the first three aspects (Ahlgren et al., 1990).

Built in 1938 and rebuilt in 1957, the Pampulha Reservoir is a touristic attraction in Belo Horizonte city. Actually, it shows an increasing eutrophication process, mainly because of domestic sewage, which is the most important problem for the lake (Giani, 1994). A plenty of limnological studies have been developed in the reservoir in the last decade. The purpose of these studies were to analyse seasonal variations in both planktonic communities and environmental parameters, their repetitivity all along the year, and to understand the key-factors associated with the observed changes (Pinto-Coelho et al., 1994).

The aims of this work were to evaluate the influence of (a) physical, chemical and climatological factors and (b) the natural fluctuation in the species composition of phytoplankton assemblages on the biochemical composition of seston in the Pampulha Reservoir, during one year study.

\section{MATERIAL AND METHODS}

Sampling was conducted monthly in a single station in the reservoir (Fig. 1). Water samples were collected at the depth of 1,0 m with a Van Dorn sampler. At the laboratory the water was filtered in pre-combusted glass fiber filters GF-50A. Large zooplankton was removed by filtration through a net of $90 \mu \mathrm{m}$ of mesh size. In this way, seston was practically constituted by phytoplankton cells. The biochemical analysis were performed on those filters.

The lipid contents were analysed following phosphofovanillin method (Zöllner \& Kirsch, 1962), with previous extraction in 2:1 chloroform- methanol (Ahlgren \& Merino, 1991). Protein contents were measured following the microbiuret method (Itzahki $\&$ Gill, 1964). Carbohydrate contents were determined with the phenol- sulfuric acid method (Herbert et al., 1971). The contents of lipid, protein and carbohydrate were expressed as concentration in $\mathrm{mg} / \mathrm{L}$. 


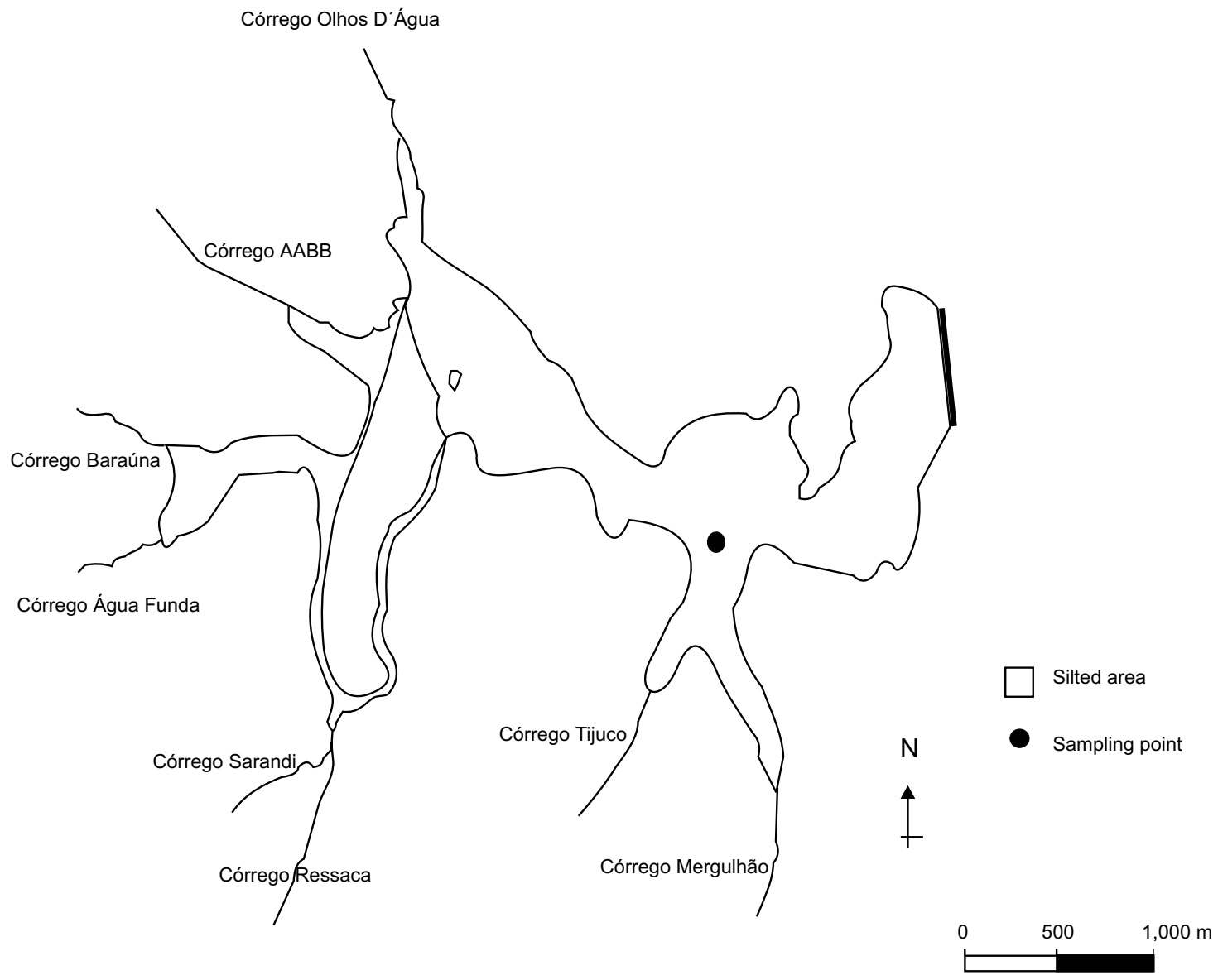

Fig. 1 - Sampling point at Pampulha Reservoir, Belo Horizonte (MG).

The physical and chemical data used in this study, as well as phytoplankton data, belong to the "Pampulha Reservoir Data Bank" - a data bank from "Pampulha Reservoir Monitoring Project". We obtained data for the following parameters: light intensity in water collum (measured by Secchi Disc), water temperature (with a termistor YSI Digital Model 30/50 FT), conductivity (with a conductivimeter YSI Digital Model 30/50 FT), dissolved oxigen contents (with an oxymeter YSI Digital Model 55/25 FT), nitrate, nitrite, ammonium concentration (according to Koroleff, 1976) and total phosphorus (according to Murphy \& Riley, 1962). The climatological data (monthly rain) were provided by the Climatological Station of Pampulha Airport.
The effects of physical, chemical and climatological parameters on biochemical composition of algae were tested by the multiple regression test (Systat for Windows VS. 5.0).

\section{RESULTS}

The area of study has got a well defined rainy season between October and March (Fig. 2).

Our results showed a general tendency for all biochemical compounds. Lipid, protein and carbohydrate levels were higher during the dry season of 1995 until the beginning of the rainy season, as verified between July/95 and October/95. 


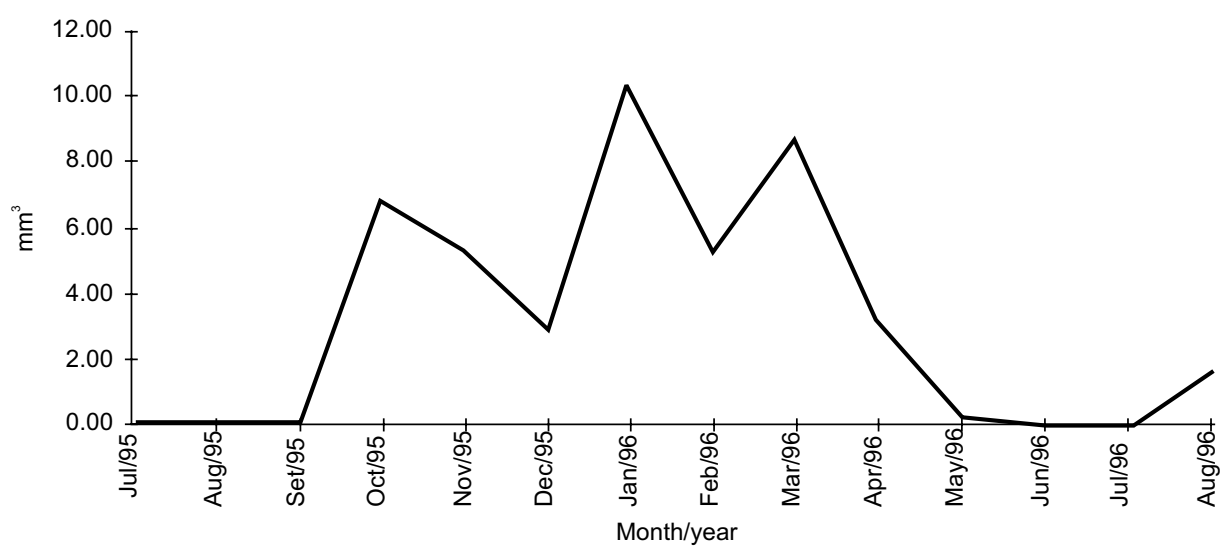

Fig. 2 - Monthly rain $\left(\mathrm{mm}^{3}\right)$ in Pampulha Reservoir, Belo Horizonte (MG).

There was a reduction in all biochemical contents during the rainy period, as observed in November/95, December/95 and January/96. At the end of this season, lipid, protein and carbohydrate concentrations increased again, between February/ 96 and April/96, except for protein contents, that increased since January $/ 96$. At the beginning of the dry season in 1996, the biochemical compounds decreased (Figs. 3, 4 and 5). It is possible that a new increase could be observed from August/96 until the beginning of the rainy season.

Changes in the biochemical composition are specially evident at the beginning and at the end of the rainy season, i.e., during climatic transition periods.
Multiple regression analysis provided significant values for the biochemical compounds and some physical, chemical and climatological parameters. It provided some partial regression coeficients that were used to build mathematical equations to describe some of the variation observed in seston biochemical composition (Table 1). According to the analysis, lipid contents could be explained by dissolved oxygen, total phosphorus, temperature and rain. Protein content could be better explained by the association among temperature, dissolved oxygen, nitrate and ammonium levels. Carbohydrates contents were better explained by light intensity and total phosphorus content.

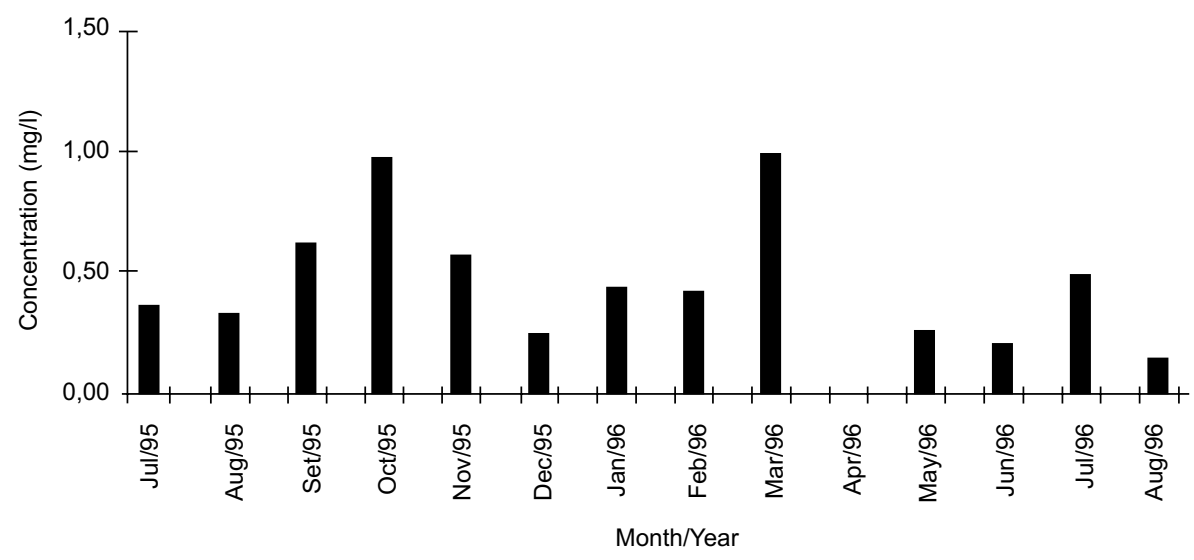

Fig. 3 - Seasonal variation in lipid contents of seston. 


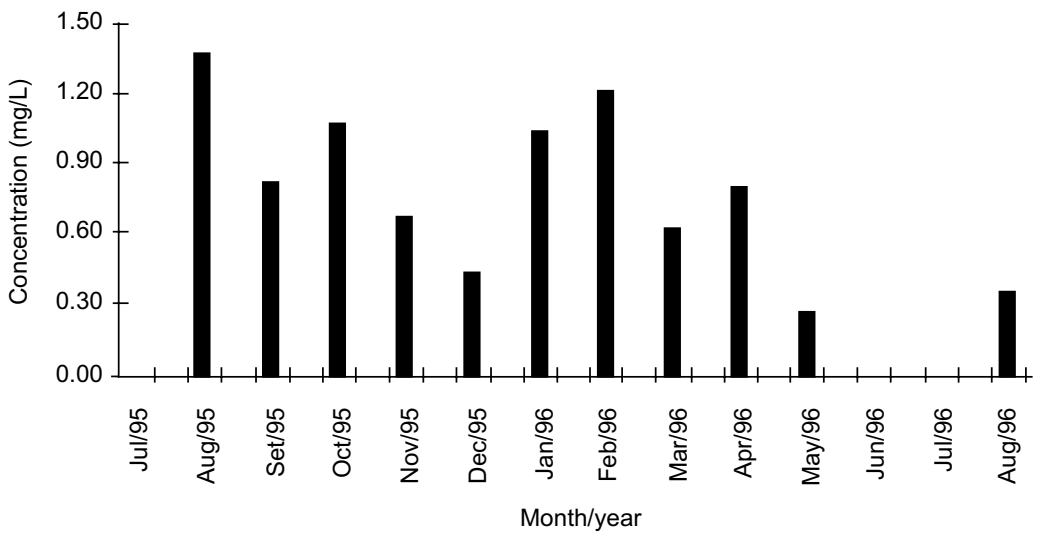

Fig. 4 - Seasonal variation in protein contents of seston.

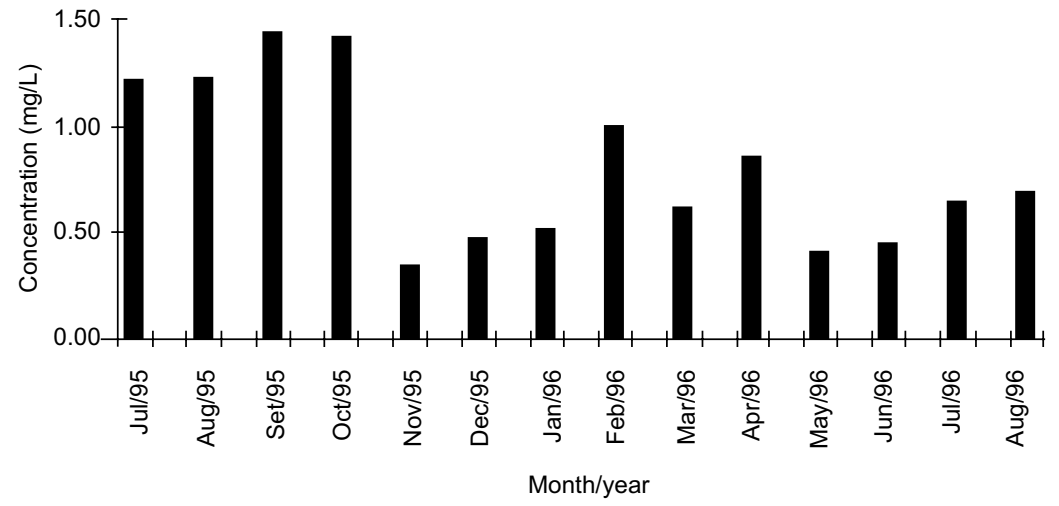

Fig. 5 - Seasonal variation in carbohydrate contents of seston.

TABLE 1

Coeficients provided by multiple regression analyses for biochemical composition of seston.

\begin{tabular}{|c|c|c|c|}
\hline $\begin{array}{c}\text { Biochemical } \\
\text { Compound }\end{array}$ & Equation & p & $\mathbf{r}^{2}$ \\
\hline Lipid & $=-0.641+[(-0.593 \mathrm{DO})+(0.739 \mathrm{R})+(0.456 \mathrm{P})+(0.355 \mathrm{~T})]$ & 0.039 & 0.680 \\
\hline Protein & $=2.213+[(-0.820 \mathrm{~T})+(0.950 \mathrm{AM})+(0.947 \mathrm{NAT})+(0.594 \mathrm{DO})]$ & 0.010 & 0.900 \\
\hline Carbohydrate & $=0.750+[(-0.162 \mathrm{LI})+(0.601 \mathrm{P})]$ & 0.038 & 0.480 \\
\hline
\end{tabular}

* Significative p values at 0.05 ; T: water temperature; LI: light intensity; R: rain; P: total phosphorus; DO: dissolved oxygen; NAT: nitrate; AM: ammonium. 
Total phytoplankton (cells. $\mathrm{ml}^{-1}$ ) showed higher densities during the dry season in 1995, between July and September (Fig. 6). Two other peaks were also observed in November/95 and between February and April/96. Low densities were present since May/96 in the reservoir.

The peaks registered reflect changes in Chlorophyta populations (Fig. 7), which is represented by many species and by the highest densities. In October/95 and July/96, Cyanobacteria showed a high number of cells. Microcystis viridis was dominant in this period (Fig. 8).
The highest densities of Euglenophyta were observed during the dry season of 1995, between July and October (Fig. 8). Pyrrophyta pointed to a peak in December/95 and May/96 (Fig. 8). The Cryptophyta Rhodomonas lacustris was dominant in these months.

\section{DISCUSSION}

Many factors seem to affect biochemical composition of phytoplankton cells, as we could see in this study.

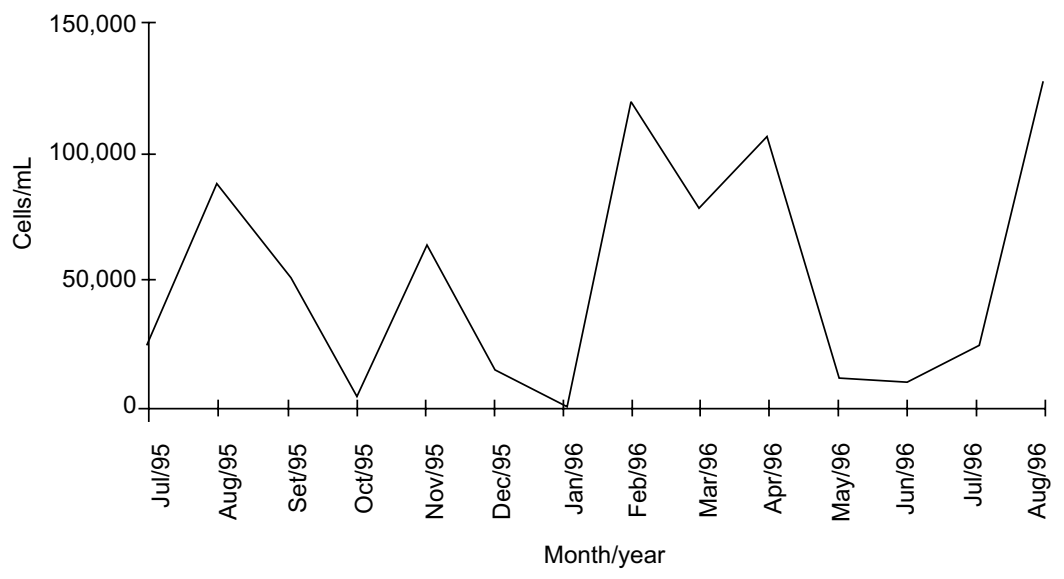

Fig. 6 - Seasonal variation in total phytoplankton densities in Pampulha Reservoir.

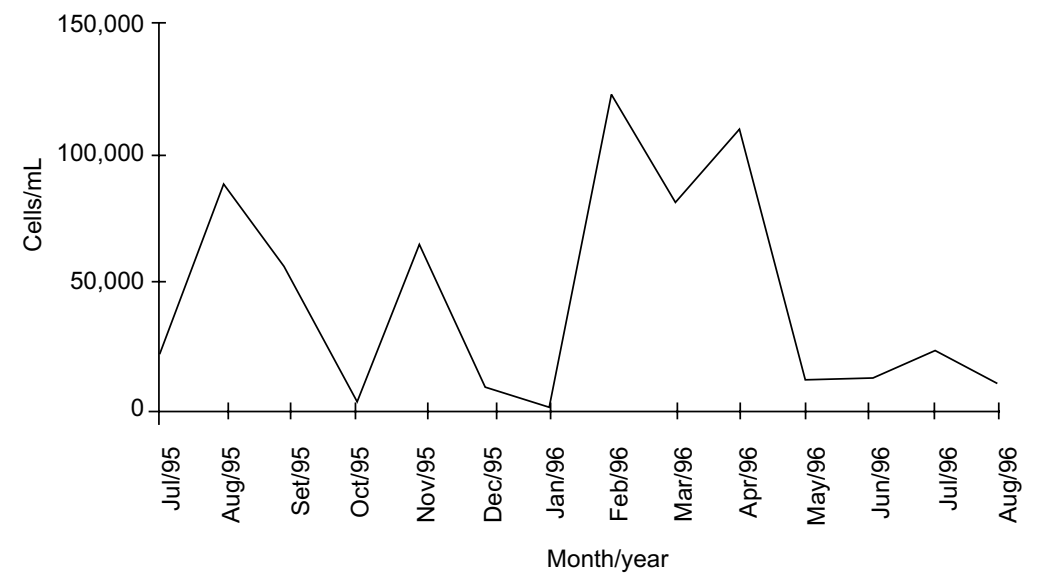

Fig. 7 - Seasonal variation in Chlorophyta densities in Pampulha Reservoir. 


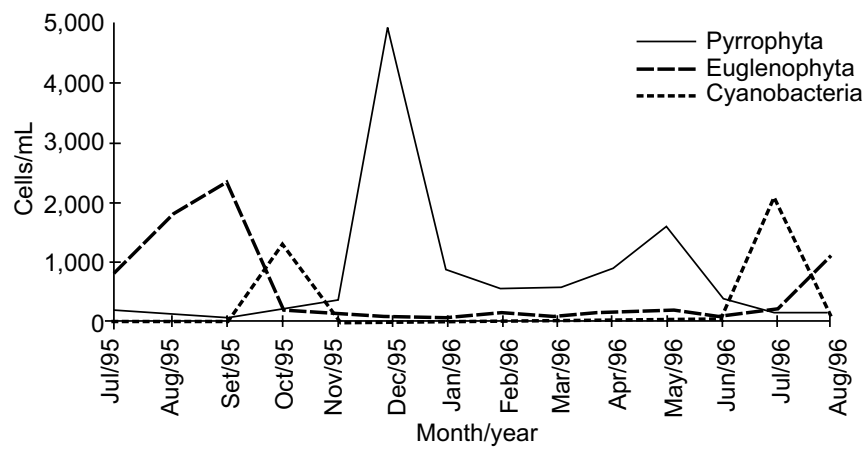

Fig. 8 - Seasonal variation in Cyanobacteria, Euglenophyta and Pyrrophyta densities in Pampulha Reservoir.

Among all the abiotic factors, the nutrient limitation had a major effect. Phosphorus contents presented a positive relationship with lipid and carbohydrate. Although a few data are available concerning the direct influence of this element on the biochemical composition, it is known that it is an essencial component for the algal metabolism, so it can limit algal growth in many environments. Its deficiency into algal cells could led to reductions in biochemical compounds synthesis, which could be associated to a weak cellular growth (Kilham et al., 1997).

Concerning to nitrogen limitation, it is known that its availability can affect the cellular compounds synthesis and storage, like pigments, proteins, carbohydrates, aminoacids, nucleic acids and lipids (Lourenço et al., 1997). There are many evidences that lipid storage can occurs as an answer to reductions of the nitrogen in the environment (Fogg, 1959). Nitrogen absence can estimulate the synthesis of non-nitrogenous compounds, like lipids and carbohydrates (Parrish \& Wangersky, 1990). In this study, no relationship was verified between carbohydrate and lipid contents and the nitrogen forms. Generally, the major part of cellular nitrogen is protein, so the nitrogen comsuption from the medium affect the protein synthesis (Smit et al., 1997). The multiple regression analysis agree with this hypothesis, since a positive coeficient was verified between protein content, nitrate and amonium.

Light intensity seems to influence the biochemical composition (Rivkin, 1989). In our study, lipid contents increased with higher light levels, while carbohydrates show an opposite pattern. It is possible that under higher light intensities a photossynthetic inhibition takes place in algal cells, in this way affecting carbohydrates synthesis. The same do not occur with lipid and protein contents.

Lipid and protein contents showed a positive relationship with water temperature, so an increasing temperature could led to increasing lipid and protein production. A large number of data concerning the effects of this parameter in photosynthesis and productivity in many algae are known, but only a few informations are available on how it could affect the biochemical composition, except by studies on specific biochemical classes, like fatty acids for instance (Wainman \& Smith, 1997).

Another factor seemed to affect the biochemical composition, namely dissolved oxygen levels. Under low dissolved oxygen levels, cells seemed to reduce their biochemical compounds, as verified here by lipid and protein contents. Oxygen may - in addition to other environmental conditions - partially affect the observed changes.

We did not find a clear seasonal pattern associated with the biochemical compounds analysed. Statistical analysis demonstred only that increasing rain could led to higher lipid contents. Nevertheless, we observed that changes in the biochemical composition occured especially during transition periods, as for instance at the beginning and at the end of the rainy season. Those interfaces correspond in Pampulha Reservoir to periods that presents changes in phytoplankton communities and also nutrient availability (Giani, 1994).

The phytoplankton composition is another factor that could have an important influence on 
the biochemical compounds. Not only the species composition, but also the nutritional status of the cells. According to Spoehr \& Milner (1949), even in periods when algal density is reduced, the lipid, protein and carbohydrate contents can be high.

In our opinion there are more than a single group affecting the biochemical composition in this study. For instance, lipid contents seemed to follow the same general pattern showed by Chlorophyta, except in October/95, when the drop in this algae density was not reflected in lipid concentrations. Perhaps another algal group, like Cyanobacteria, that pointed out an increase in this period, could be affecting the lipid contents. Microcystis viridis, for instance, was dominant in the reservoir in that month. Kenyon (1972) found that Microcystis sp cells present a high polyunsaturated fatty acids content. In a smaller scale the same could have happened in July/96 in Pampulha Reservoir.

The high protein concentrations found in the dry season of 1995 reflect the high algal densities registered in that period, like Chlorophyta and Euglenophyta, comparing to the dry season in 1996. Some species showed growth peaks occasionally, and this can help to explain some of the observed variations. Although phytoplankton densities were low in the reservoir in December/95, there was a still high protein level. It could have suffered an influence of Pyrrophyta, showed by a peak, mainly constituted by Rhodomonas lacustris. This algae is known to have a high protein content (Giani, 1991).

Carbohydrate contents seemed to have a similar behaviour. They pointed out high concentrations during the dry season in 1995, when phytoplankton densities were high, and between February and April/96, June and July/96. Probably the Chlorophyta species had a major effect upon carbohydrate levels in the reservoir.

Some conclusions can be taken from this work, concerning the relationships between the biochemical composition and abiotic and biotic factors. Nutrient availability (nitrogen and phosphorus), temperature, light intensity and rain can affect biochemical composition of plankton in different ways. All the effects have to be understood as a whole. Algal composition also plays a role in the protein, lipid and carbohydrate contents, especially the dominant groups.
No factors work isolated from each other upon the biochemical composition, and the sum of different interactions results in the seasonal changes here recorded.

Acknowledgments - We thank C. C. Figueredo for phytoplankton counting and the Pampulha Airport for climatological data. This research was partially supported by $\mathrm{CNPq}, \mathrm{PRPq} / \mathrm{UFMG}$ and SMMA/PBH and by a CNPq fellowship to I.G.B.

\section{REFERENCES}

AHLGREN, G., LUNDSTEDT, L., BRETT, M. \& FORSBERG, C., 1990, Lipid composition and food quality of some freshwater phytoplankton for cladoceran zooplankters. J. Plankton. Res., 12(4): 809818 .

AHLGREN, G. \& MERINO, L., 1991, Lipid analysis of fresh water microalgae: a method study. Arch. Hydrobiol., 121(3): 295-306.

BUTLER, N. M., 1994, Lipid storage in Diaptomus kenai (Copepoda; Calanoida): effects of inter- and intraespecific variation in food quality. Hydrobiologia, 274(13): 9-16.

FÁBREGAS, J., PATIÑO, M., ARREDONDO-VEGA, B. O., TOBAR, J. L. \& OTERO, A., 1995, Renewal rate and nutrient concentration as tools to modify productivity and biochemical composition of cyclostat cultures of the marine microalga Dunaliella tertiolecta. Appl. Microbiol. Biotechnol., 44: 287-292.

FERNANDÉZ-REIRIZ, M. J., PÉREZ-CAMACHO, M. J. F. A., BLANCO, M. P. J., CAMPOS, M. J. \& LABARTA, U., 1989, Biomass production and variation in the biochemical profile (total protein, carbohydrates, RNA, lipids and fatty acids) of seven species of marine microalgae. Aquaculture, 83: 17-37.

FOGG, G. E., 1959, Nitrogen nutrition and metabolic patterns in algae. Symposia Soc. Exptl. Biol., 13: 106-125.

GIANI, A., 1991, Implications of phytoplannkton chemical composition for zooplânkton production: experimental evidence. Oecologia, 87: 409-416.

GIANI, A., 1994, Limnology in Pampulha Reservoir: some general observations with emphasis in phytoplankton community. In: R. M. Pinto-Coelho, A. Giani \& E. Von Sperling (1992), Ecology and human impact on lakes and reservoirs in Minas Gerais. Belo Horizonte, MG, 193p.

HERBERT, D., PHIPPS, P. J. \& STRANGE, R. E., 1971, Chemical analysis of microbial cells. In: J. R. Norris \& D. W. Ribbons (1971), Methods in microbiology, v. 5B. Academic Press, NY, 244p.

ITZHAKI, R. F. \& GILL, D. M., 1964, A Micro-Biuret Method for estimating proteins. Analyt. Biochem., 9: 401-410. 
KENYON, C. N., 1972, Fatty acid composition of unicellular strains of blue-green algae. J. Bacteriol., 109: 827-834.

KILHAM, S., KREEGER, D. A., GOULDEN, C. E. \& LYNN, S. G., 1997, Effects of nutrient limitation on biochemical constituints of Ankystrodesmus falcatus. Fresh. Biol., 38: 591-596.

KOROLEFF, F., 1976, Determination of nutrients. In: K. Grashof (ed.), Methods of seawater analysis. Verlag Chemie Weihim, pp. 117-181.

LOURENÇO, S. O., MARQUEZ, U. M. L., MANCINIFILHO, J., BARBARINO, E. \& AIDAR, E., 1997, Changes in biochemical profile of Tetraselmis gracilis I - Comparison of two culture media. Aquaculture, 148: $153-168$.

MILlER, J. D. A., 1962, Fats and Steroids. In: R. A Lewin (1962), Physiology and Biochemistry of Algae. Academic Press, NY, 929p.

MURPHY, J. \& RILEY, J. P., 1962, A modified single solution method for determination of phosphate in natural waters. Analytica Chimica Acta, 27: 31-36.

PARRISH, C. C. \& WANGERSKY, P. J., 1990, Particulate and dissolved lipid classes in cultures of Phaeodactylum tricornutum in cage culture turbidostats with a range of nitrogen supply rates. Mar. Ecol. Prog. Ser., 35: 119128.

PERCIVAL, E., 1979, The polysaccharides of green, red and brown seaweeds: their basic structure, biosynthesis and function. Br. Phycol. J., 14: 103-117.

PINTO-COELHO, R. M., GIANI, A. \& VON SPERLING, E., 1994, Ecology and human impact on lakes and reservoirs in Minas Gerais. Belo Horizonte, MG, $193 \mathrm{p}$.
RIVKIN, R. B., 1989, Influence of irradiance and spectral quality on the carbon metabolism of phytoplankton. I. Photosynthesis, chemical composition and growth. Mar. Ecol. Prog. Ser., 55: 291-304.

SICKO-GOAD, L. \& ANDERSEN, N. A., 1991, Effect of growth and light/dark cycles on diatom lipid content and composition. J. Phycol., 27: 710-718.

SMIT, A. J., ROBERTSON, B. L. \& DU PREEZ, D. R., 1997, N pulse concentrations and frequency, tank condition and nitrogen starvation on growth rate and biochemical composition of Gracillaria gracilis. J. Appl. Phycol., 8: 473-481.

SPOEHR, H. A. \& MILNER, H. W., 1949, The chemical composition of Chlorella; effect of environmental conditions. Plant. Physiol., 24: 120-149.

STRYER, L., 1988, Biochemistry. 3a ed., Stanford University, 939p.

WAINMAN, B. C. \& SMITH, R. E. H., 1997, Can physicochemical factors predict lipid content in phytoplankton? Fresh. Biol., 38: 571-579.

ZÖLLNER, N. \& KIRSCH, K., 1962, Über die quantitative Bestimmung von Lipoiden (Mikromethode) mittels der vielen natürlichen Lipoiden (allen bekannten Plasmolipoiden) gemeinsamen Sulfophosphovanillin-Reaktion. Zeits. fiir die gesam. Exp. Medizin, 135: $545-561$ 